\title{
Tracing Waste-Water in River and Ground Water of Orange County Using Boron Isotopes and General Geochemistry
}

\author{
Avner Vengosh \\ Lee Davisson \\ Tom Bullen
}

March 26, 1999

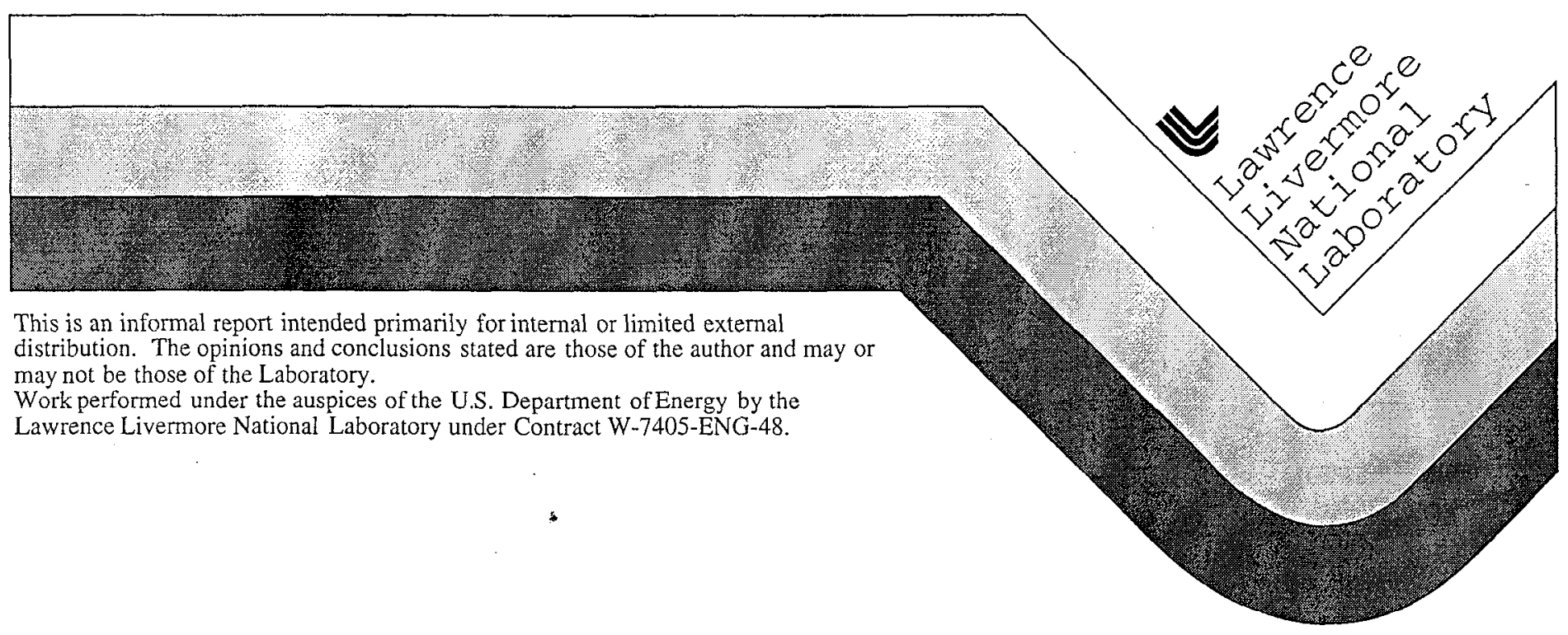




\section{DISCLAIMER}

This document was prepared as an account of work sponsored by an agency of the United States Government. Neither the United States Government nor the University of California nor any of their employees, makes any warranty, express or implied, or assumes any legal liability or responsibility for the accuracy, completeness, or usefulness of any information, apparatus, product, or process disclosed, or represents that its use would not infringe privately owned rights. Reference herein to any specific commercial product, process, or service by trade name, trademark, manufacturer, or otherwise, does not necessarily constitute or imply its endorsement, recommendation, or favoring by the United States Government or the University of California. The views and opinions of authors expressed herein do not necessarily state or reflect those of the United States Government or the University of California, and shall not be used for advertising or product endorsement purposes.

This report has been reproduced directly from the best available copy.

Available to DOE and DOE contractors from the Office of Scientific and Technical Information

P.O. Box 62, Oak Ridge, TN 37831

Prices available from (615) 576-8401, FTS 626-8401

Available to the public from the

National Technical Information Service

U.S. Department of Commerce

5285 Port Royal Rd.,

Springfield, VA 22161 
Tracing Waste-Water in River and Ground Water of Orange County Using Boron Isotopes and General Geochemistry

\author{
Avner Vengosh ${ }^{1}$, Lee Davisson ${ }^{2}$, Tom Bullen $^{3}$
}

Final Report

March 26, 1999

1. University of California Santa Cruz and Hydrological Service, Israel

2. Isotope Science Division, Lawrence Livermore National Laboratory,

3. Division of Water Resources, US Geological Survey, Menlo Park, CA 


\section{Introduction}

Surface water runoff within the Santa Ana River (SAR) watershed is generated from a variety of sources, including mountain snowmelt, urban waste-water discharge, and dairy feedlots. During summer baseflow periods, the persistent flow of approximately 200 cubic feet per second (cfs) consists almost entirely of tertiary-treated waste-water from upstream urban discharge. The Orange County Water District (OCWD) artificially recharges the majority of flow from the SAR during high and low flow periods into the Forebay region to augment groundwater pumping demands. Proposed regulations for reclaimed water recharge into potable use aquifers have direct impact on how OCWD manages groundwater recharge from the SAR. Knowledge of how much treated waste-water recharges into the Forebay area of the Orange County Groundwater Basin has direct benefit to future management and regulatory activities.

This project attempted to trace the inorganic components of waste-water dissolved in the SAR and local groundwater in the Forebay by applying genchemical and boron isotopic systematics. The objectives were to characterize the chemical and boron isotopic compositions of recharged surface water and groundwater, to delineate typical mixing end-members, and to examine if recharge water from the SAR has a different isotopic signature relative to non-anthropogenically-influenced groundwater. The overall goal is to test whether a combination of boron isotopes and water chemistry will provide an accurate means to quantifiably distinguish waste-water from non-waste water sources in surface and groundwater of the Forebay.

\section{Analytical Procedures}

Boron isotopic compositions in samples were determined by negative themal ionization mass spectrometry (NTIMS; Vengosh et al., 1989; Eisenhut et al., 1996). Boron was directly loaded onto rhenium single filaments with addition of B-free sea water matrix, and analyzed by reverse polarity and "dynamic" collection, on a Finnigan MAT-261 mass spectrometer at the US Geological Survey, Menlo Park, California. Some samples were also analyzed with an NBS mass spectrometer at the University of California at Santa Cruz. The mode of filament loading and mass spectrometry procedures were strictly repeated in samples, sea water, and NBS-SRM standards in order to minimize the variability of mass spectrometer induced isotopic discrimination. A standard deviation of up to $2 \%$ was determined by NIST SRM-951 replicates. Isotope ratios are reported as per mil deviation

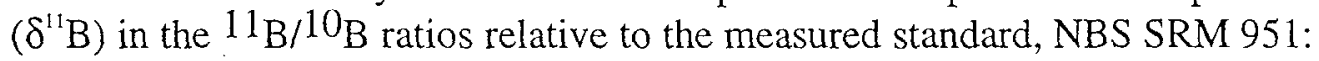

$$
\delta^{11} \mathrm{~B}=\left[\left({ }^{11} \mathrm{~B} /{ }^{10} \mathrm{~B}\right)_{\text {sample }} /\left({ }^{11} \mathrm{~B} /{ }^{10} \mathrm{~B}\right)_{\mathrm{NBS} 951}-1\right] \times 1000 .
$$

The mean of the absolute ${ }^{11} \mathrm{~B} /{ }^{10} \mathrm{~B}$ ratios of NIST SRM-951 replicates, analyzed with the samples was $4.010 \pm 0.005$. Chemical data of the samples were supplied by the OCWD water quality lab. All results are listed in Table 1.

\section{Results and Discussion}

Surface and ground water samples (ten of each) were collected in the mid-lower SAR watershed and the Forebay of Orange County (Table 1). Surface water included waste-water discharges from various treatment plants, the river water up- and down-stream with respect to waste-water discharges, and two recharge ponds (Anaheim Lake and Warner Basin). Groundwater, ranging from ages of 0.1 to $>40$ years old, was sampled at various distances and depths from the recharge ponds (Davisson et al., 1998). One sample (HBM-1/8) was collected from a deep, confined aquifer approximately 10 miles 
downgradient of the Forebay in order to measure the "pre-development" isotopic and geochemical abundances in groundwater believed not to have been influenced by anthropogenic activities.

The results of the boron isotopic analysis are illustrated in Figure 1. The variation in $\delta^{11} \mathrm{~B}$ of surface water and waste-water discharge into SAR are constrained to a somewhat narrow range and show a strong overlap with groundwater $\delta^{11} \mathrm{~B}$ compositions. However, some groundwaters have a much higher $\delta^{11} \mathrm{~B}$, which can be related to older groundwater, but this is not always the case. One sample representing runoff from dairy feedlots in the Chino Basin (Mill Creek), had a distinctly lower $\delta^{11} \mathrm{~B}$ value $(6.0 \%)$ compared to urban waste-water discharge. Details of these isotopic signatures and their respective water chemistries are discussed below.
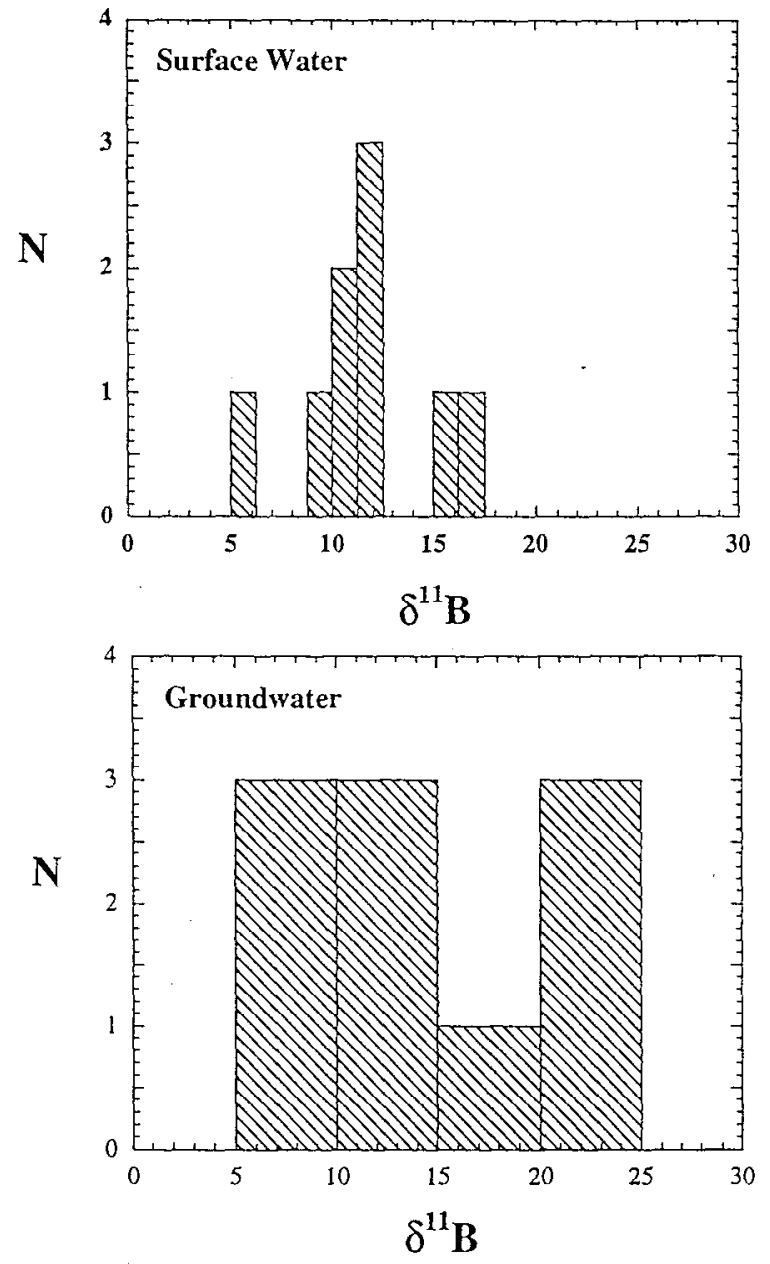

Figure 1. Histograms of $\delta^{11} \mathrm{~B}$ values shows considerable overlap among surface water of the SAR, waste-water discharge into the SAR, and groundwater samples from the Forebay.

\section{Surface Water}

Surface water samples were collected March 16, 1998 during a baseflow period following large runoff events in February (Fig. 2). During the February storms, severe flooding occurred in dairies of the Chino Basin area in the SAR watershed, and as a result, high nutrient loads were flushed down the SAR into recharge ponds. During the March sampling, TOC concentrations were unusually high in Mill Creek, SAR at Imperial Headgates (SAR-IMP), and in both Anaheim Lake and Warner Basin (see Table 1). The mean daily flow of the SAR below Prado Dam on March $16^{\text {th }}$ was 510 cubic feet per 
second (cfs). Exact flows of waste-water discharge on this day are not known, however, mean annual flow is estimated at 138 million gallons per day. This is equivalent to a daily mean average of $214 \mathrm{cfs}$.

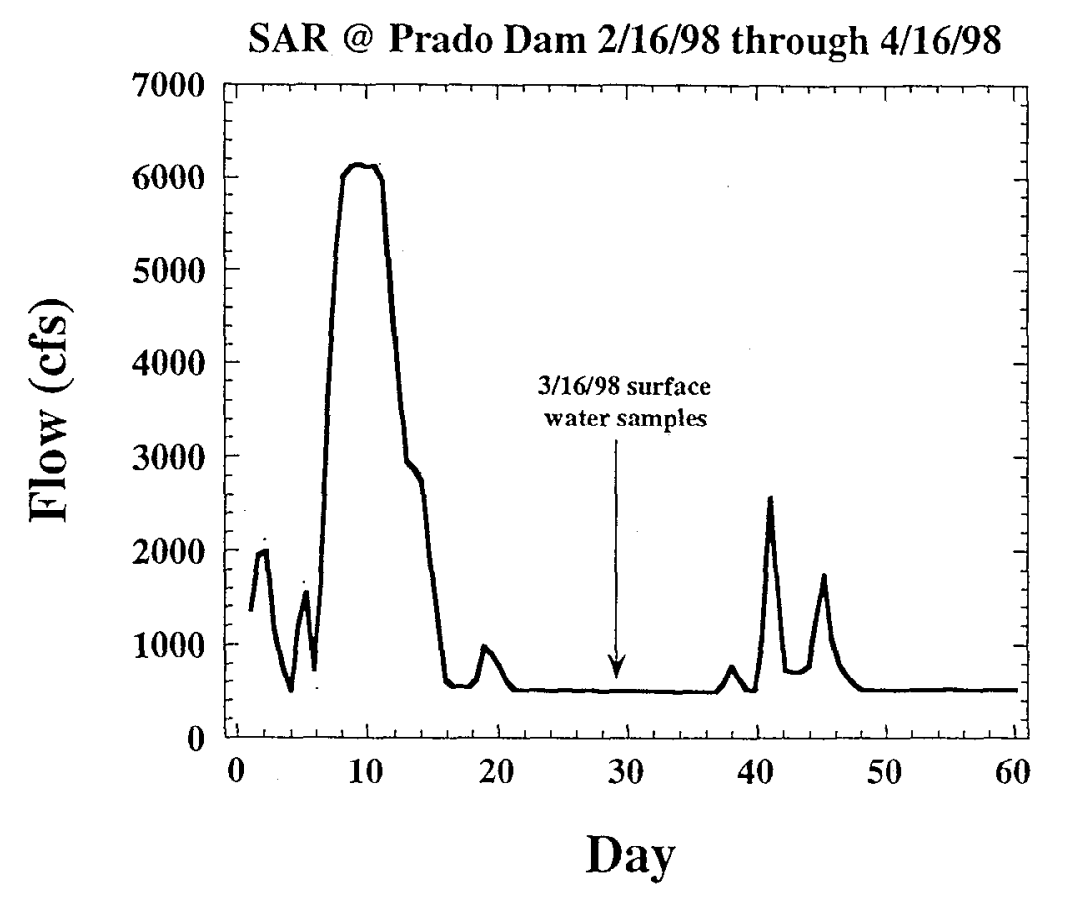

Figure 2. Flow in cubic feet per second measured in the Santa Ana River below Prado Dam from mid-February to mid-April. Samples collected for boron isotopic analyses were collected $3 / 16 / 98$, during baseflow.

Upstream SAR water, collected at Waterman Bridge, had low TDS (162 mg/L) relative to the downstream SAR sampling points and waste-water discharge $(462-674 \mathrm{mg} / \mathrm{L})$. Boron content in the upstream water is also low $(0.05 \mathrm{mg} / \mathrm{l})$ relative to downstream and waste-waters $(0.21-0.38 \mathrm{mg} / \mathrm{L})$. The concentration of boron in the upstream sample was too low to measure a boron isotopic value. The boron isotopic value measured in Mill Creek, which discharged a component of dairy runoff in March, was the lowest at $6.0 \%$. The boron isotopic composition of the SAR-IMP $\left(\delta^{11} \mathrm{~B}=12.1 \%\right.$ ) is similar to that of waste-water discharged to the SAR (a $\delta^{11} \mathrm{~B}$ range of $10.2 \%$ to $12.4 \%$ ). The $\delta^{11} \mathrm{~B}$ values of the SAR waste-water discharge is similar to the isotopic ratios measured in waste-waters in Israel (a range of $5.3 \%$ to $11.2 \%$; Vengosh et al., 1994) and overlap also with those of natural Na-borates (0\%o to $10 \%$ ), which are used in the detergent industry as bleaching agents. Recent analyses of synthetic Naborates from California also show a similar range from $-0.4 \%$ to $7.6 \%$ (Vengosh, 1997).

Consequently, the boron isotopic composition of waste-waters that are discharged to SAR is typical of Na-borate added to detergents and washing powders, which subsequently are released during their degradation. Thus, the waste-water component appeared to dominate the inorganic chemical composition of SAR at Imperial Headgates. This is expected since the upstream river has low dissolved salts relative to that of the waste-waters.

However, on closer inspection, the downstream surface water chemistry appears to have an additional salt source. This is seen by comparing $\mathrm{B}$ concentration with $\mathrm{Cl}$ in the samples measured (Fig. 3). If SAR-IMP comprised a simple mixture between waste-water and upstream SAR, then it, as well as Anaheim Lake and Warner Basin, should lie along a mixing line in Figure 3. As observed, surface water samples lie to the right of the mixing line, suggesting that an additional source of salt that is lower in B and higher in $\mathrm{Cl}$ mixes in as well. Three explanations for this may be 1 ) B sorbs to clay-rich sediments in the SAR, which reduces the dissolved concentration before reaching SAR-IMP, 2) evaporation in the of impounded surface water behind Prado Dam increases the $\mathrm{Cl}$ and $\mathrm{B}$ 
concentration, or 3) rising groundwater behind Prado Dam, which may have higher TDS, including higher boron, mixes with the surface runoff. The first two explanations are not consistent with the data. In particular, the first alternative cannot explain the groundwater $\mathrm{B}$ and $\mathrm{Cl}$ concentrations, which show greater deviation from the mixing line (Fig. 3). The second alternative requires conservation of the $\mathrm{B} / \mathrm{Cl}$ ratio during evaporation, but the actual ratio is lower in the SAR-IMP sample.

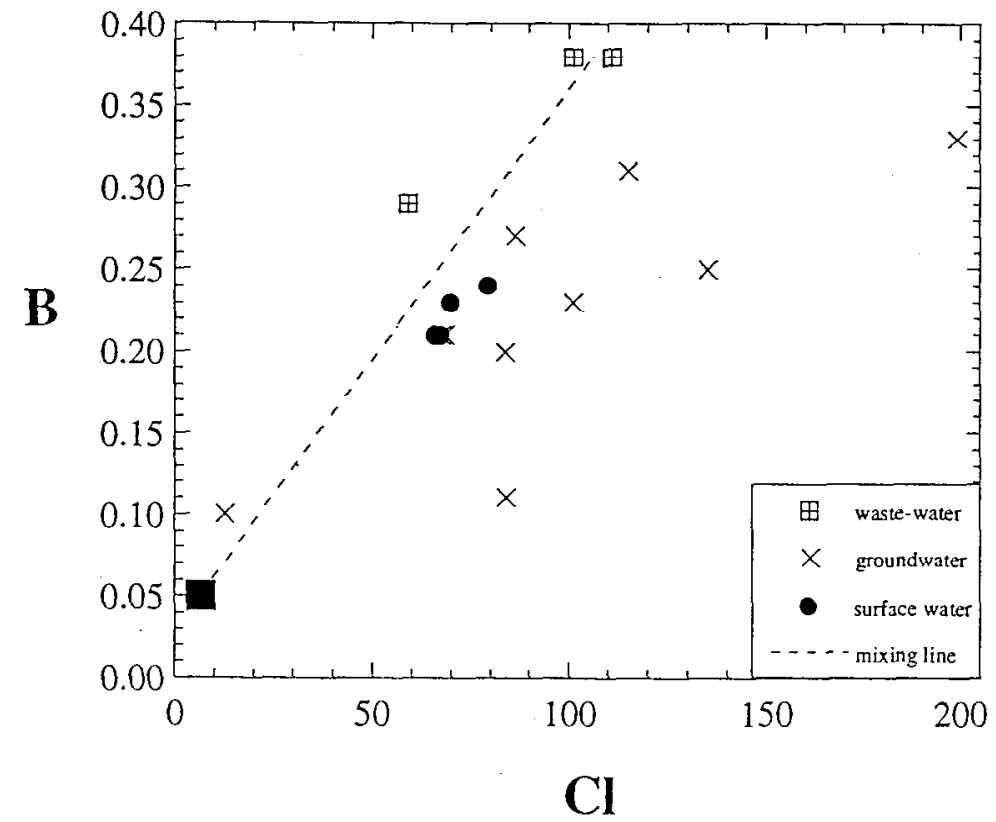

Figure 3. A mixing line between upstream SAR at Waterman (black square) with waste-water discharge does not pass through surface water samples collected downstream in SAR-IMP and recharge basins, suggesting an additional salt source mixing into surface water.

Anaheim Lake has a $\delta^{11} \mathrm{~B}$ composition (9.8 and 10.7\% ) similar to, but slightly less than SAR-IMP, while Warner Basin (16.2 and 17.1\%o) was distinctly higher. Both recharge basins were filled continuously with SAR-IMP water and typically have mean residence times of $<1$ month. No simple explanation for higher $\delta^{11} \mathrm{~B}$ signatures in Warner Basin is obvious from data in Table 1.

\section{Young Groundwater}

Below is part of Table 1 that compares the boron isotopic compositions and chemistry of surface water in the Forebay recharge area to shallow groundwater thought to be recharged directly from the recharge basins. In particular, the geochemistry of Anaheim Lake water is compared to groundwater (sampled one month later) from wells A-27 and AMD-9/1. Previous tracer work showed that groundwater from both these wells tends to be approximately one month old recharge from Anaheim Lake with virtually no dilution from other recharge sources. Also, groundwater from well AM-5A is compared to Warner Basin. AM-5A has been ${ }^{3} \mathrm{H}-{ }^{3} \mathrm{He}$ dated to $<1$ year old, but exact arrival times and dilution from the recharge source is not known. 
Geochemistry of Recharge Basins and Groundwater They Directly Recharge.

\begin{tabular}{|lccccccccccccc}
\hline & $\mathrm{B}$ & $\delta^{11} \mathrm{~B}$ & age yrs & $\mathrm{Ca}$ & $\mathrm{Mg}$ & $\mathrm{Na}$ & $\mathrm{K}$ & $\mathrm{Cl}$ & $\mathrm{SO}_{4}$ & $\mathrm{HCO}_{3}$ & $\mathrm{NO}_{3}-\mathrm{N}$ & $\mathrm{TDS}$ & $\mathrm{TOC}$ \\
Anaheim Lake 39 ft & 0.21 & 9.8 & & 60.2 & 15.4 & 53.9 & 20.0 & 67.0 & 97.7 & 161.0 & 2.9 & 488 & 11.1 \\
Anaheim Lake 5 ft & 0.21 & 10.7 & & 60.9 & 15.7 & 54.1 & 20.3 & 66.9 & 99.0 & 165.0 & 2.8 & 494 & 11.2 \\
& & & & & & & & & & & & \\
AMD-9/1 & 0.21 & 9.7 & 0.1 & 60.0 & 18.7 & 67.3 & 6.7 & 67.5 & 102.0 & 176.0 & 0.2 & 499 & 3.6 \\
A-27 & 0.21 & 6.9 & 0.1 & 61.6 & 18.9 & 68.1 & 6.6 & 68.4 & 100.0 & 177.0 & 0.4 & 502 & 3.0 \\
& & & & & & & & & & & & & \\
Warner Basin 50 ft & 0.21 & 16.2 & & 61.1 & 16.4 & 52.0 & 22.6 & 65.9 & 103.0 & 170.0 & 1.8 & 499 & 12.8 \\
Warner Basin 5 ft & 0.23 & 17.1 & & 63.9 & 17.7 & 57.9 & 22.8 & 69.9 & 113.0 & 180.0 & 2.0 & 534 & 12.6 \\
AM-5A & & & & & & & & & & & & \\
\end{tabular}

Comparison of Anaheim Lake to A-27 and AMD-9/1 reveals that the B concentration didn't change. The boron isotopic abundance of AMD-9/1 is nearly identical to Anaheim Lake, while A-27 is slightly lower. The Ca didn't change between the recharge water and groundwater samples, however, there is an increase in $\mathrm{Mg}$ and $\mathrm{Na}$ and a large decrease in $\mathrm{K}$. The anions of $\mathrm{Cl}, \mathrm{SO}_{4}$, and $\mathrm{HCO}_{3}$ show a slight increase, while $\mathrm{NO}_{3}$ clearly decreased. The decreased $\mathrm{NO}_{3}$ likely demonstrates denitrification during recharge. In addition, there is a significant decrease in TOC with recharge.

The recharge basin was very "bio-active" in March due to high nutrient loads in the surface water. Note that the dissolved oxygen levels are low and TOC is high in the recharge basins (see Table 1). The sediment-water interface during recharge might control the reduction of nitrate. The geochemistry of AM-5A is somewhat dissimilar to Warner Basin. In particular, AM-5A had higher $\mathrm{B}, \mathrm{Na}$, and $\mathrm{Cl}$, and a boron isotope value closer to Anaheim Lake. Groundwater from AM-5A may have travel times from Warner Basin greater than one month, and was possibly mixed with other recharge sources.

Well AM-14, which has been ${ }^{3} \mathrm{H}-{ }^{3} \mathrm{He}$ age dated to 3 years old, has a B concentration and isotopic abundance (12.1\%o) similar to SAR-IMP water (see Table 1). It also had a lower $\mathrm{K}$ concentration and a higher $\mathrm{Na}$ and $\mathrm{Cl}$, similar to AM-5A.

\section{Older Groundwater $(<40$ years)}

Two additional groundwaters were sampled that are known to be influenced by artificial recharge, but have older ages. Well $\mathrm{A}-42$ has a $\delta^{18} \mathrm{O}$ composition (-8.0\%) identical to the SAR-IMP and was age dated to be 18 years old (Davisson et al., 1996). The low $\delta^{18} \mathrm{O}$ value (-9.94\%o) of AMD-7/8 shows an approximately $50 \%$ Colorado River recharge component and has an age date of 30 years (ClemensKnott et al., 1998). Both of these samples have ages and $\delta^{18} \mathrm{O}$ values consistent with artificial recharge practices during a period when waste-water discharge occurred in the SAR watershed.

A-42 has a B concentration similar to SAR-IMP, but a boron isotope value much higher $(20.8 \%$ ). Likewise, it has a higher dissolved solids content than SAR-IMP and younger groundwaters discussed above. AMD-7/8 has a lower B concentration, but a similar boron isotope value (19.3\%o) to A-42. AMD-7/8 also has a higher dissolved solids content, in particular a higher $\mathrm{SO}_{4}$, which is consistent with a Colorado River influence.

Non-Anthropogenically-Influenced Groundwater

Four groundwaters were sampled that represent recharge that either occurred before any extensive agricultural and urban development in Orange County or is of local origin and unaffected by artificial recharge waters. The latter include AM-1 and AM-2, which are shallow wells east of Anaheim Lake and at the base of the Chino Hills. Another sample measured located in the western Forebay is AMD$7 / 13$, which is $>40$ years old and likely was recharged before Prado Dam was installed (Clemens-Knott 
et al., 1998). HBM-1/8 is a deeper groundwatcr sampled in a confined aquifer approximately 10 miles west of the Forebay and probably is on the order of 1000's of years old.

Both AM-1 and AM-2 have surprisingly high TDS levels accompanied by B concentrations similar to SAR-IMP and waste-water discharge. These groundwaters also have significantly higher $\mathrm{SO}_{4}$ and $\mathrm{Cl}$ concentrations. Their boron isotopic signatures are distinctly different, with AM-1 (11.8\%o) similar to SAR-IMP and AM-2 (22.0\%) similar to A-42. Groundwater in AM-1 and AM-2 may be influenced by leaching of soluble salts from the marine sediments of the Chino Hills.

Chemical data was not available for AMD-7/13, but the field conductivity measurement (381 $\mu S)$ indicates a low TDS. The boron isotope value (14.5\%o) is slightly higher than measured in modern SAR-IMP. HBM-1/8 has a similarly low conductivity $(372 \mu \mathrm{S})$, a low B concentration $(0.1 \mathrm{mg} / \mathrm{L})$, and a boron isotope value (24.2\%o) similar to AM-2. Note that HBM-1/8 and AMD-7/13 have nearly identical conductivities, but have different boron isotope values.

\section{Comparison of Groundwater with Surface Water}

A comparison between the chemical compositions of surface and ground water is given in Figure 4. The data show that surface and ground waters have similar $\mathrm{Na} / \mathrm{Cl}$ ratios $(\sim 1.05)$, groundwater is relatively enriched in $\mathrm{Cl}, \mathrm{Ca}, \mathrm{Mg}$, and $\mathrm{SO}_{4}$, and surface water is relatively enriched in $\mathrm{K}$ and $\mathrm{B}$. Thus, it is essentially impossible to determine the impact of waste-water on the chemical composition of regional groundwater based major ion variations alone. For example, waste-water in Israel has high $\mathrm{Cl}$ and $\mathrm{SO}_{4}$ concentrations relative to local ground water. Hence, these parameters are sensitive to wastewater contamination. In contrast, water samples in the eastern Forebay that represent nonanthropogenically-influenced groundwater (AM-1 and AM-2) with no impact of artificial recharge have even higher $\mathrm{Cl}, \mathrm{SO}_{4}$, and $\mathrm{Ca}$ contents relative to the SAR-LMP water. Consequently, it seems that inorganic geochemistry alone can not be used to trace the influence of recharged waste-water in the Forebay. 

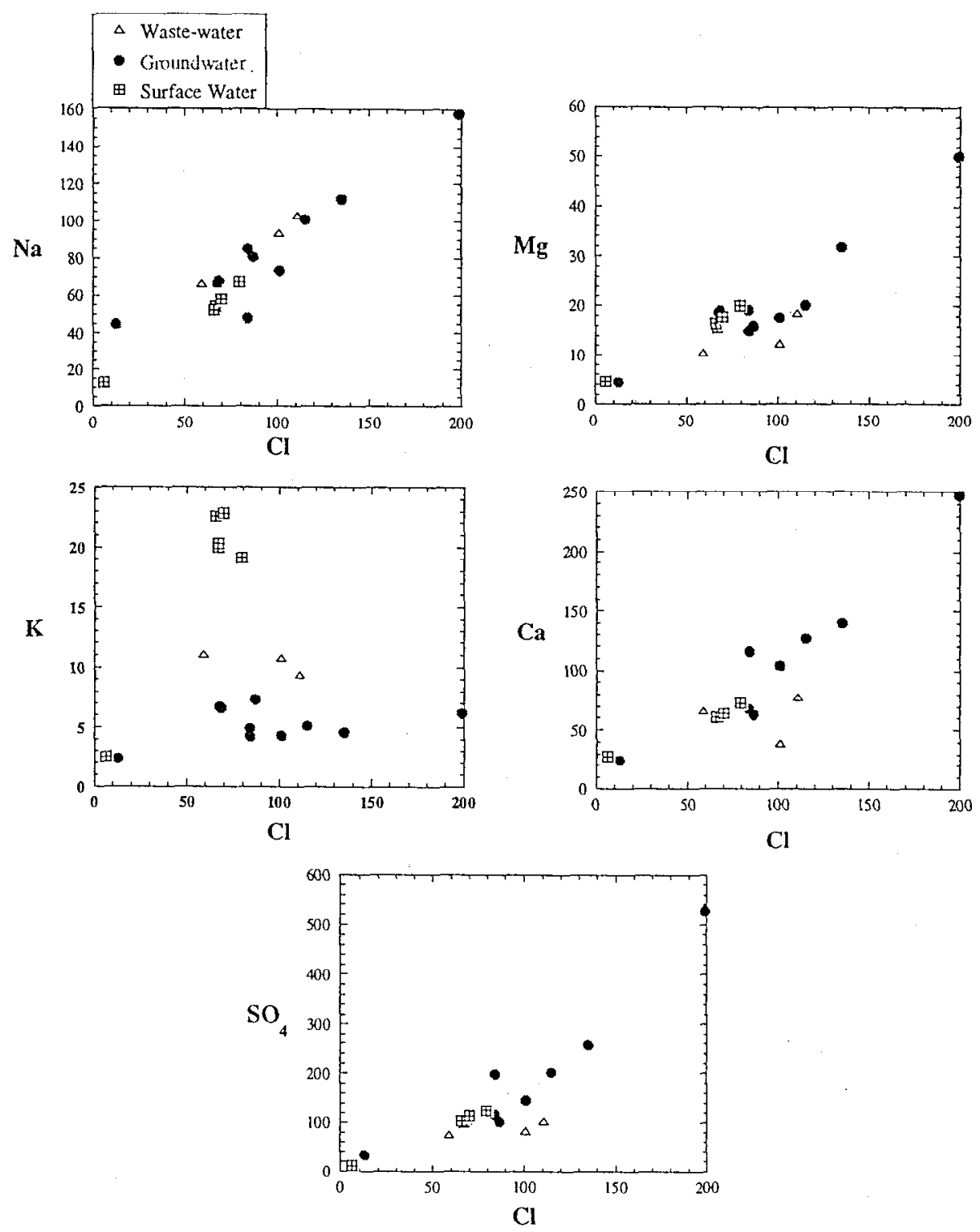

Figure 4. Variations of $\mathrm{Cl}$ vs. different ions of investigated surface and ground water samples from the Forebay. Note the enrichments of $\mathrm{Cl}, \mathrm{Ca}$, and $\mathrm{Mg}$ (in $\mathrm{mg} / \mathrm{L}$ ) in ground water relative to surface water.

In general, groundwater measured in this study had a lower $\mathrm{B} / \mathrm{Cl}$ ratio than waste-water discharge in the SAR watershed. Young groundwater generally had an indistinguishable $\mathrm{B} / \mathrm{Cl}$ ratio from SAR-IMP and the recharge basins, with the exception of AM-14. With the exception of Warner Basin, the $\delta^{11} \mathrm{~B}$ composition of surface water is similar to the young groundwater, having values less than $-13.0 \%$. The two older groundwaters sampled, however, have lower $\mathrm{B} / \mathrm{Cl}$ ratios and higher $\delta^{11} \mathrm{~B}$ values. With the exception of AM-1, the $\delta^{11} \mathrm{~B}$ composition of non-anthropogenically-influenced groundwater is also higher, but with variable $\mathrm{B} / \mathrm{Cl}$ ratios. 


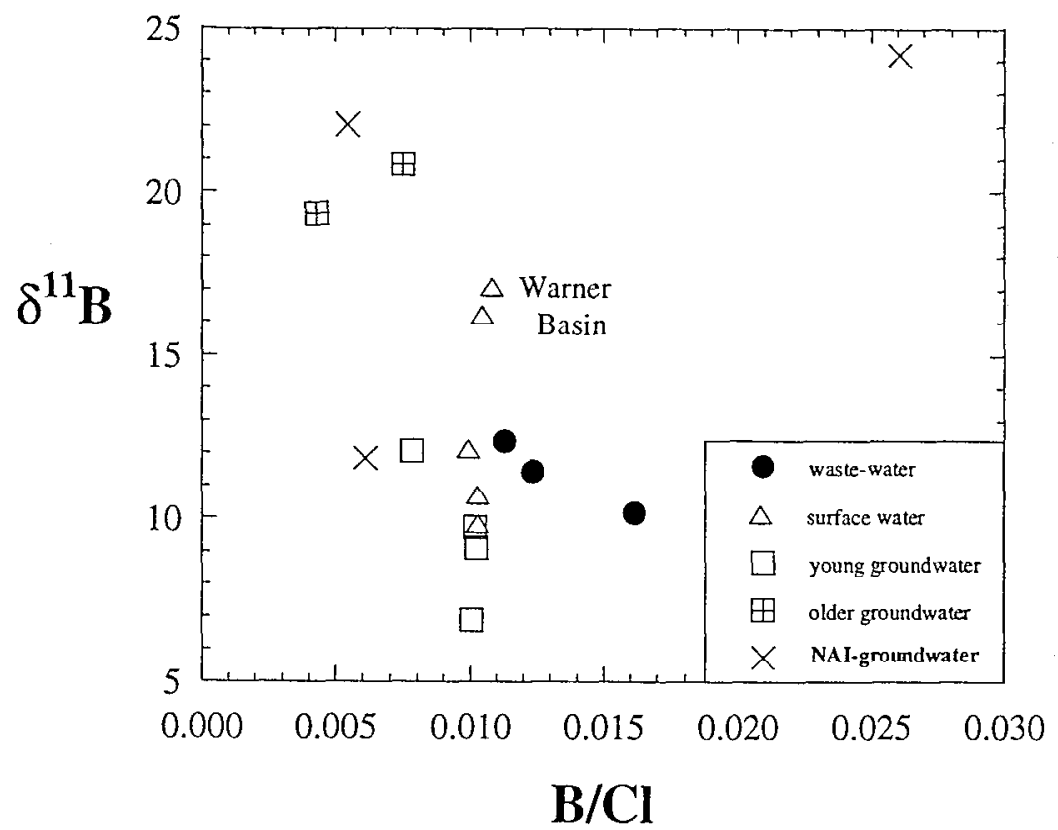

Figure $5 . \mathrm{B} / \mathrm{Cl}$ ratio vs. $\delta^{11} \mathrm{~B}$ values of waste-water, surface water, and groundwater samples. Note that with the exception of Warner Basin young groundwaters had $\mathrm{B} / \mathrm{Cl}$ ratios and $\delta^{11} \mathrm{~B}$ values similar to the surface water. NAI-groundwater is non-anthropogenically-influenced groundwater.

\section{Mixing Model for SAR}

The mean daily flow of the SAR measured below Prado Dam was $510 \mathrm{cfs}$ on the day samples were collected (Fig. 2). Mean annual flow of waste-water discharges throughout the SAR watershed total 138 million gallons per day, or an average flow rate of $214 \mathrm{cfs}$. Using these numbers, the waste-water comprised $42 \%$ of the flow on the day the samples were collected.

Assuming that only two end-members (waste-water and upstream SAR) contributed to flow and water chemistry measured at SAR-IMP, a mass balance model can be used to independently derive relative mixtures using chemical constituents. In such a case, the fraction of waste-water is

$$
\mathrm{F}=\left[\mathrm{C}_{\text {downstream }}-\mathrm{C}_{\text {upstream }}\right] /\left[\mathrm{C}_{\text {waste }}-\mathrm{C}_{\text {upstream }}\right]
$$

where $\mathrm{C}$ is the concentration of a particular aqueous species measured. Below is tabulated the calculated fractions of waste-water mixtures using $\mathrm{Cl}, \mathrm{Na}$, and $\mathrm{B}$ (in $\mathrm{mg} / \mathrm{L}$ ) measured in $\mathrm{SAR}$ at Waterman, averages of waste-water discharge, and SAR-IMP. F is the fraction of waste-water at SAR-IMP using the two end-member mixing model.

\begin{tabular}{ccccc} 
Element & SAR Waterman & SAR-IMP & Waste-water & F \\
\hline $\mathrm{Cl}$ & 6.1 & 79 & 93 & 0.84 \\
$\mathrm{Na}$ & 12.7 & 68 & 89 & 0.71 \\
$\mathrm{~B}$ & 0.05 & 0.24 & 0.36 & 0.61
\end{tabular}

As can be seen in the calculations above, the fraction of waste-water (61-84\%) derived from mass balance is much larger than derived from measured flow (42\%). Therefore, it is likely that an additional water source with a higher salt content is also being added to SAR (see also Fig. 3). One 
potential source is local groundwater of a character similar to AM-1 and AM-2. Both these groundwaters have similar $\mathrm{B}$ concentrations and higher $\mathrm{Cl}$ and $\mathrm{Na}$ than the waste-water discharge. Groundwater of this character could discharge into the SAR water behind Prado Dam as rising groundwater, with possibly a small additional contribution into the SAR channel between Prado Dam and SAR-IMP. Therefore, a three end-member mixing model may be more realistic. Preliminary calculations with three cnd-member mixing (using AM-2 as the local groundwater component and assuming waste-water discharge contributes $42 \%$ of SAR-IMP flow) suggested that $25 \%$ of the flow at SAR-IMP is from local groundwater. Further work is needed to test a three end-member mixing model.

\section{Conclusions and Recommendations}

In general, waste-water, surface water, and young groundwater recharge had a similarly low $\delta^{11} \mathrm{~B}$ composition reflecting significant detergent related sources for boron. In addition, nonanthropogenically-influenced groundwater recharge had a much higher $\delta^{11} \mathrm{~B}$ value. However, the $\delta^{11} \mathrm{~B}$ of Warner Basin was exceptionally higher than SAR-IMP and Anaheim Lake. Likewise, the $\delta^{11} \mathrm{~B}$ of non-anthropogenically-influcnced groundwater from AM-1 was much closer to SAR-IMP. Older groundwater recharged from 18-30 years ago had a $\delta^{11} \mathrm{~B}$ composition similar to non-anthropogenicallyinfluenced groundwater. Dairy runoff had a distinctly low $\delta^{11} \mathrm{~B}$ value compared to all samples measured.

All groundwater sampled had a somewhat higher dissolved solid content reflected in $\mathrm{Na}, \mathrm{Ca}, \mathrm{Cl}$, and $\mathrm{SO}_{4}$ concentrations higher than in waste-water and surface water. Non-anthropogenicallyinfluenced water in the eastern Forebay had the highest TDS that may result from leaching of soluble salts from marine sediments of the Chino Hills. The higher TDS of groundwater makes tracing wastewater mixtures using cation and anion abundances alone difficult.

The chemistry of SAR-IMP appears not to be a simple mixture of waste-water and upstream runoff. Instead, a third mixing component, tentatively suggested to be local groundwater, contributes to slightly higher dissolved salt contents. Local groundwater may mix with runoff as rising groundwater behind Prado Dam.

Seasonal water quality data sets of waste-water discharge and SAR flows could be used to further test mixing models and to delineate components of flow in the SAR watershed. A successful mixing model may be able to determine the fraction of waste-water in SAR-IMP at different times of the year. Samples for these data sets should be collected in one to two day periods to obtain a "snapshot" of water quality chemistry.

The $\delta^{11} \mathrm{~B}$ results for this limited database showed some spurious results that raise some doubt to its utility as a waste-water tracer. However, samples collected last March represented an unusual period when nutrient loads were inordinately high. Inorganic and organic reactions during this period could possibly have had an unforeseen and poorly understood affect on the $\delta^{11} \mathrm{~B}$ results. Therefore, followup analyses during a typical runoff period and during baseflow may be warranted. 


\section{References}

Clemens-Knott, D., Foster, J.H., Yoshiba, G., Davisson, M.L., Hudson, G.B., Beiriger, J. (1998) Hydrogeochemical study of waters on the lower Forebay region of the Santa Ana River-coastal groundwater basin, Orange County, CA. Report to the Orange County Water District, 18 pgs.

Davisson M.L., Hudson G.B., Herndon, R., Niemeyer S., Beiriger, J. (1996) Report on the feasibility of using isotopes to source and age-date groundwater in Orange County Water District's Forebay Region, Orange County, California. Lawrence Livermore National Lab UCRL-ID-123953, 36 pgs.

Davisson M.L., Hudson, G.B., Moran, J.E. and Niemeyer, S. (1998) Isotope tracer approaches for characterizing artificial recharge and demonstrating regulatory compliance. Annual UC Water Reuse

Research Conference, June 4-5, 1998, Monterey, California.

Eisenhut, S., Heumann K.G. , Vengosh A. (1996) Determination of boron isotopic variations in aquatic systems with negative thermal ionization mass spectrometry as a tracer for anthropogenic influences. Fresenius J. Anal. Chem., 354, 903-909.

Heumann, K.G. (1982) Isotopic analyses of inorganic and organic substances by mass spectrometry. Int. J. Mass Spectrom. Ion Phys., 45, 87-110.

Vengosh, A., Chivas, A.R. and McCulloch, M.T (1989). Direct determination of boron and chlorine isotopes in geological materials by negative thermal-ionization mass spectrometry. Chemical Geology (Isotope Geoscience Section), 79; 333-343.

Vengosh, A., Heumann, K.G., Juraske, s., and Kasher, R. (1994) Boron isotope application for tracing sources of contamination in groundwater. Environ. Sci. \& Tech., 28, 1968-1974.

Vengosh, A. and Keren, R. (1996). Chemical modifications of groundwater contaminated by recharge of sewage effluent. Journal of Contaminant Hydrology , 23, 347-360.

Vengosh, A. and Pankratov, I. (1998) $\mathrm{Br} / \mathrm{Cl}$ and $\mathrm{F} / \mathrm{Cl}$ variations of domestic sewage effluents and associated contaminated ground water. Ground Water, in press. 
Table 1: Geochemical Data of Surface and Ground Water in the SAR Watershed and the Anaheim Forebay.

\begin{tabular}{|c|c|c|c|c|c|c|c|c|c|c|c|c|c|c|c|c|}
\hline & Type & Date & EC & $\mathrm{pH}$ & DO & $\delta^{11} B$ & $\mathrm{~B}$ & $\mathrm{Ca}$ & $\mathrm{Mg}$ & $\mathrm{Na}$ & $\mathbf{K}$ & $\mathrm{CI}$ & $\mathrm{SO}_{4}$ & $\mathrm{HCO}_{3}$ & $\mathrm{NO}_{3}-\mathrm{N}$ & TOC \\
\hline \multicolumn{17}{|l|}{ Surface Water } \\
\hline WR-RIX-01 & waste water & $3 / 16 / 98$ & 737 & 6.63 & 7.1 & 10.20 & 0.29 & 66.4 & 10.5 & 66.9 & 11.1 & 59.1 & 74.7 & 185.0 & 7.3 & 2.3 \\
\hline RP-HVefluent & waste water & $3 / 16 / 98$ & 994 & 7.14 & 5.8 & 12.37 & 0.38 & 77.7 & 18.5 & 103.0 & 9.4 & 111.0 & 103.0 & 248.0 & 0.8 & 4.7 \\
\hline WR- Chino RP2 & waste water & $3 / 16 / 98$ & 749 & 6.96 & 6.0 & 11.45 & 0.38 & 38.5 & 12.4 & 93.7 & 10.8 & 101.0 & 82.8 & 116.0 & 6.4 & 7.3 \\
\hline SW-RP2 & dairy runoff & $3 / 16 / 98$ & 1039 & 7.32 & 8.1 & 5.96 & 0.32 & 38.5 & 12.4 & 93.7 & 10.8 & 101.0 & 82.8 & 116.0 & 1.5 & 26.2 \\
\hline SAR-waterman & no waste influence & $3 / 16 / 98$ & 206 & 7.56 & 8.7 & - & 0.05 & 27.1 & 4.6 & 12.7 & 2.5 & 6.1 & 12.7 & 91.6 & 1.1 & 4.3 \\
\hline SAR IMP HG & river water, mix & $3 / 16 / 98$ & 892 & 7.44 & 7.4 & 12.12 & 0.24 & 72.8 & 20.0 & 67.6 & 19.1 & 79.2 & 124.0 & 206.0 & 2.2 & 11.5 \\
\hline Anaheim Lake $39^{\prime}$ & recharge water & $3 / 17 / 98$ & 724 & 7.27 & 3.2 & 9.82 & 0.21 & 60.2 & 15.4 & 53.9 & 20.0 & 67.0 & 97.7 & 161.0 & 2.9 & 11.1 \\
\hline Anaheim Lake $5^{\prime}$ & recharge water & $3 / 17 / 98$ & 729 & 7.24 & 3.0 & 10.70 & 0.21 & 60.9 & 15.7 & 54.1 & 20.3 & 66.9 & 99.0 & 165.0 & 2.8 & 11.2 \\
\hline Warner lake 50' & recharge water & $3 / 17 / 98$ & 740 & 7.09 & 0.1 & 16.22 & 0.21 & 61.1 & 16.4 & 52.0 & 22.6 & 65.9 & 103.0 & 170.0 & 1.8 & 12.8 \\
\hline Warner Lake 5' & recharge water & $3 / 17 / 98$ & 779 & 7.22 & 2.7 & 17.09 & 0.23 & 63.9 & 17.7 & 57.9 & 22.8 & 69.9 & 113.0 & 180.0 & 2.0 & 12.6 \\
\hline \multicolumn{17}{|c|}{ Young Groundwater } \\
\hline AMD-9 Level 1 & 1 month old & $4 / 15 / 98$ & 766 & 7.90 & - & 9.72 & 0.21 & 60.0 & 18.7 & 67.3 & 6.7 & 67.5 & 102.0 & 176.0 & 0.2 & 3.6 \\
\hline$A-27$ & 1 month old & $4 / 15 / 98$ & 778 & 7.90 & - & 6.89 & 0.21 & 61.6 & 18.9 & 68.1 & 6.6 & 68.4 & 100.0 & 177.0 & 0.4 & 3.0 \\
\hline AM-5A & $1 \mathrm{yr}$ old & $4 / 10 / 98$ & 825 & 7.70 & - & 9.11 & 0.27 & 63.2 & 16.0 & 80.9 & 7.3 & 86.5 & 101.0 & 182.0 & 0.5 & 1.4 \\
\hline AM-14 & $2-3$ yrs old & $3 / 17 / 98$ & 882 & 7.60 & - & 12.08 & 0.20 & 67.8 & 14.9 & 85.1 & 4.9 & 83.8 & 115.0 & 179.0 & 4.6 & 0.7 \\
\hline \multicolumn{17}{|c|}{ Older Groundwater } \\
\hline$A-42$ & 18 yrs old & $3 / 16 / 98$ & 948 & 7.20 & - & 20.83 & 0.23 & 104.0 & 17.5 & 73.6 & 4.3 & 101.0 & 145.0 & 206.0 & 0.9 & 0.9 \\
\hline AMD 7/1/mp8 & 26 yrs old & $7 / 13 / 98$ & 921 & 8.00 & - & 19.34 & 0.11 & 116.0 & 19.1 & 48.1 & 4.2 & 84.0 & 198.0 & 167.0 & 0.4 & 0.5 \\
\hline \multicolumn{17}{|c|}{ Non-Anthropogenically-Influenced Groundwater } \\
\hline AM-1 & local recharge & $3 / 17 / 98$ & 1470 & 7.50 & - & 11.83 & 0.25 & 140.0 & 31.8 & 112.0 & 4.6 & 135.0 & 257.0 & 284.0 & 4.3 & 0.8 \\
\hline AM-2 & local recharge & $3 / 16 / 98$ & 2290 & 7.20 & - & 22.03 & 0.33 & 247.0 & 50.1 & 158.0 & 6.2 & 199.0 & 528.0 & 418.0 & 1.0 & 1.2 \\
\hline AMD $7 / 1 / \mathrm{mp} 13$ & pre-Prado Dam & $7 / 13 / 98$ & 381 & 8.30 & - & 14.47 & - & & & & & & & & & - \\
\hline HBM $1 / 1 \mathrm{mp} 8$ & est. $>1000$ yrs old & $7 / 13 / 98$ & 372 & 8.40 & - & 24.20 & 0.10 & 24.0 & 4.4 & 44.5 & 2.4 & 12.6 & 32.9 & 123.0 & $<0.1$ & 0.7 \\
\hline
\end{tabular}

$\mathrm{EC}$ is in $\mu \mathrm{S} . \delta^{11} \mathrm{~B}$ is in per mil deviations from NBS standard. All other analyses are reported as $\mathrm{mg} / \mathrm{L}$. 